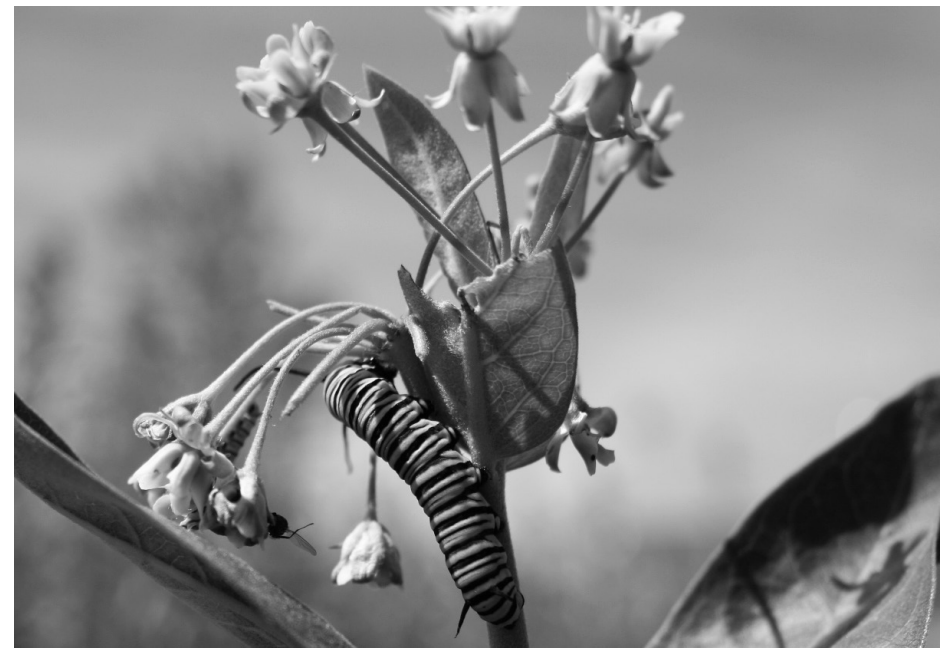

Photo - Monarch Caterpillar - Lois Vanthuyne, EC-CWS Last Mountain Lake NWA

\title{
INSECTS
}

\section{AN UNPARALLELED INFLUX OF MONARCHS}

\section{Phillip S. Taylor, Saskatoon, SK Tel: 306 665-6371}

In 2012, a record number of Monarch butterflies (Danaus plexippus) arrived in prairie Canada beginning in late May spreading northwest through Manitoba, Saskatchewan and into Alberta where they are normally rare. ${ }^{1} \mathrm{~A}$ new citizen science web site eButterfly.ca, dedicated to monitoring changes in Canadian butterfly populations, states this flight is unprecedented in 140 years. After wintering in the central Mexican highlands adults break their hibernation and begin to migrate north in mid-March, most stopping in the southern United States when they encounter milkweed plants sought for laying their eggs. The Monarch's reproductive cycle is short, as little as 4 to 7 weeks depending on the local environment: egg (7-10 days), caterpillar (14-21 days), pupa (7-21 days), then emerging as fresh adults (http://www.naturenorth.com/summer/ monarch/monarchF2.html). ${ }^{2}$ This summer generation of Monarchs continues north as conditions allow. Cool weather slows development. Thousands arrive in eastern Canada each spring, accompanied by a few over wintering adults (up to $10 \%$ ) and later in the summer by more second generation summer adults. ${ }^{2}$

The first Monarchs arriving in Saskatchewan this spring flew strongly and were bright in colour showing little wear. Brenda Kramarchuk reported the first Monarch, at Last Mountain Bird Observatory, on 25 May and except for the days of howling winds, staff at Last Mountain Lake National Wildlife Area saw 1 or 2 most days after that (R. Dickson, pers comm.). Craig Salisbury saw his first Monarch in his Saskatoon garden 
on May 26, two to three weeks earlier than normal; and he stated that females began to lay large numbers of eggs on host milkweed plants in his yard almost immediately upon arrival (C. Salisbury, pers comm.). By the first week of June Monarchs were seen in many locations north and west of Saskatoon with numbers peaking a week later near Redberry Lake Biosphere Reserve. During the second and third weeks of June butterflies were seen with increasing frequency near Edmonton (http://www.cbc.ca/news/ technology/story/2012/06/20/monarchbutterfly-migration-alberta.html). On July 9, I counted 65 Monarch caterpillars on 176 milkweed plants in a native plant garden in Saskatoon. The plants were between 10 and $80 \mathrm{~cm}$ in height and approximately half were in flower. These late instar caterpillars ranged in length from just under $20 \mathrm{~mm}$ (9) to just over $50 \mathrm{~mm}$ (24); the latter were approaching their maximum size, before pupating. The following three mornings between 0930 and $1030 \mathrm{hr}$, I watched adult females, with very drab and frayed wings, lay pale green eggs on the upper and lower leaf surfaces of Showy Milkweed (Asclepias speciosa). By 15 July most of the caterpillars could not be found and many of the plants were stripped of their leaves. Monarchs unerringly find isolated milkweed plants in meadows, open areas and urban gardens, even within in the aspen and southern boreal transition forest regions of the Prairie Provinces. ${ }^{3,4}$ Five species of native milkweed grow in Saskatchewan. ${ }^{5}$ However, when their preferred milkweeds are not available, caterpillars are occasionally found on Dogbane (Apocynum sp). I observed one worn female lay single eggs on nearby Sow Thistle (Sonchus sp) and Red Osier Dogwood (Cornus stolonifera) leaves on 12 July.

There have been other big years for Monarch butterflies in Saskatchewan.
Bernie and Mike Gollop describe 1997 as the "year of the Monarch" when butterflies appeared first on 5 June at Waskesiu and were seen through out the southern part of the province until 9 September near Roche Perce. ${ }^{4}$ In 2007 impressive numbers were seen from Calgary, Alberta eastward. Juhachi Asai, Saskatoon, states, "In 2007, four chrysalises were given to me on September 13 and I kept them in the Monarch cage until the adults emerged. The adults came out on September 16, 17 and 18. We tagged them and they were released." (J. Asai pers comm.). The last Monarch recorded for Saskatchewan in 2007 was on 2 October in Saskatoon. ${ }^{6}$

Some fall generation adults have been recorded flying in mid October in Manitoba but most leave our region in September. ${ }^{7}$ These fall Monarchs delay breeding and will live 8 to 9 months enabling them to make their way back to Mexico for the winter, a trip of up to $4000 \mathrm{~km}$; the next spring they then begin their migration north. Amazingly they complete these migrations without previous experience. A Canadian zoologist, Fred Urquhart, pioneered wing tagging of Monarchs to unravel their mysterious movements which eventually lead to the discovery of their wintering areas west of Mexico City in 1975 (http://www.monarchwatch. org/news/urquhart.htm). In 2010 a Monarch Butterfly Biosphere Reserve was established to protect 56,000 ha of this critical pine-oak forest. (http:// en.wikipedia.org/wiki/Monarch_Butterfly_ Biosphere_Reserve)

You can contribute your Monarch sightings including numbers, locations and dates of caterpillars and adults, to eButterfly. $c a$, thereby helping to document this extraordinary 2012 event which to date has seen steady numbers of butterflies appear for an extended number of weeks. 
1. Bird CD, Hilchie GJ, Kondla NG, Pike EM and Sperling FAH (1995) Alberta Butterflies. The Provincial Museum of Alberta, Edmonton. 349pp.

2. Salisbury, Lorriene and Craig (2000) A Monarch diary. Blue Jay: 58(2):95-98.

3. Klassen P, Westwood AR, Preston WB, and McKillop WB (1989) The Butterflies of Manitoba. Manitoba Museum of Man and Nature, Winnipeg. 290 pp.

4. Gollop B and Gollop M (1998) 1997 year of the Monarch in Saskatchewan. Blue Jay: 56(1):55-62.
5. Leighton A (1998) Milkweed: the Monarch's prairie host. Blue Jay 58(1):4654.

6. Brooks S (2008) Monarchs in my milkweed. Blue Jay 66(3):175-176.

7. Hooper RR (1973) The Butterflies of Saskatchewan. Saskatchewan Department of Natural Resources, Regina. $216 \mathrm{pp}$.

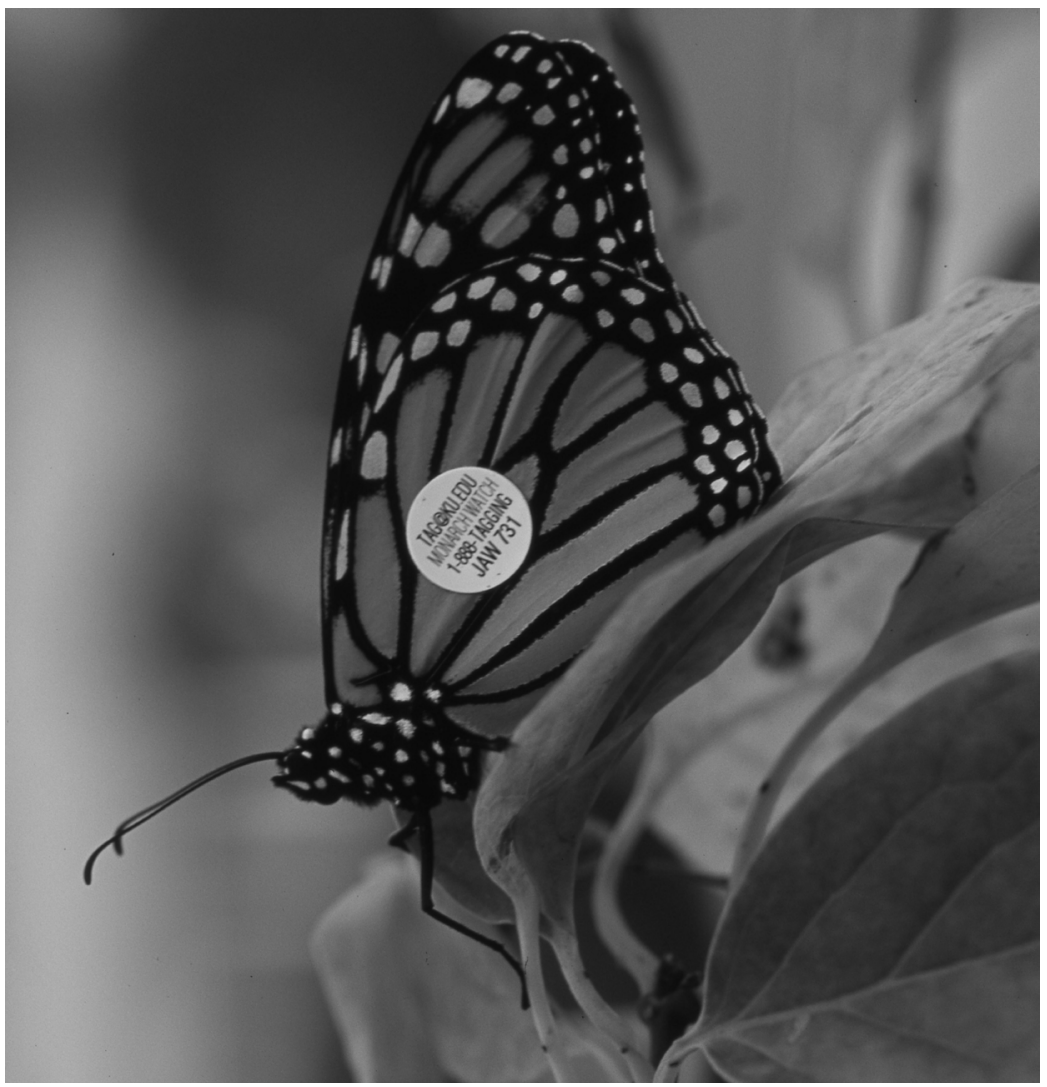



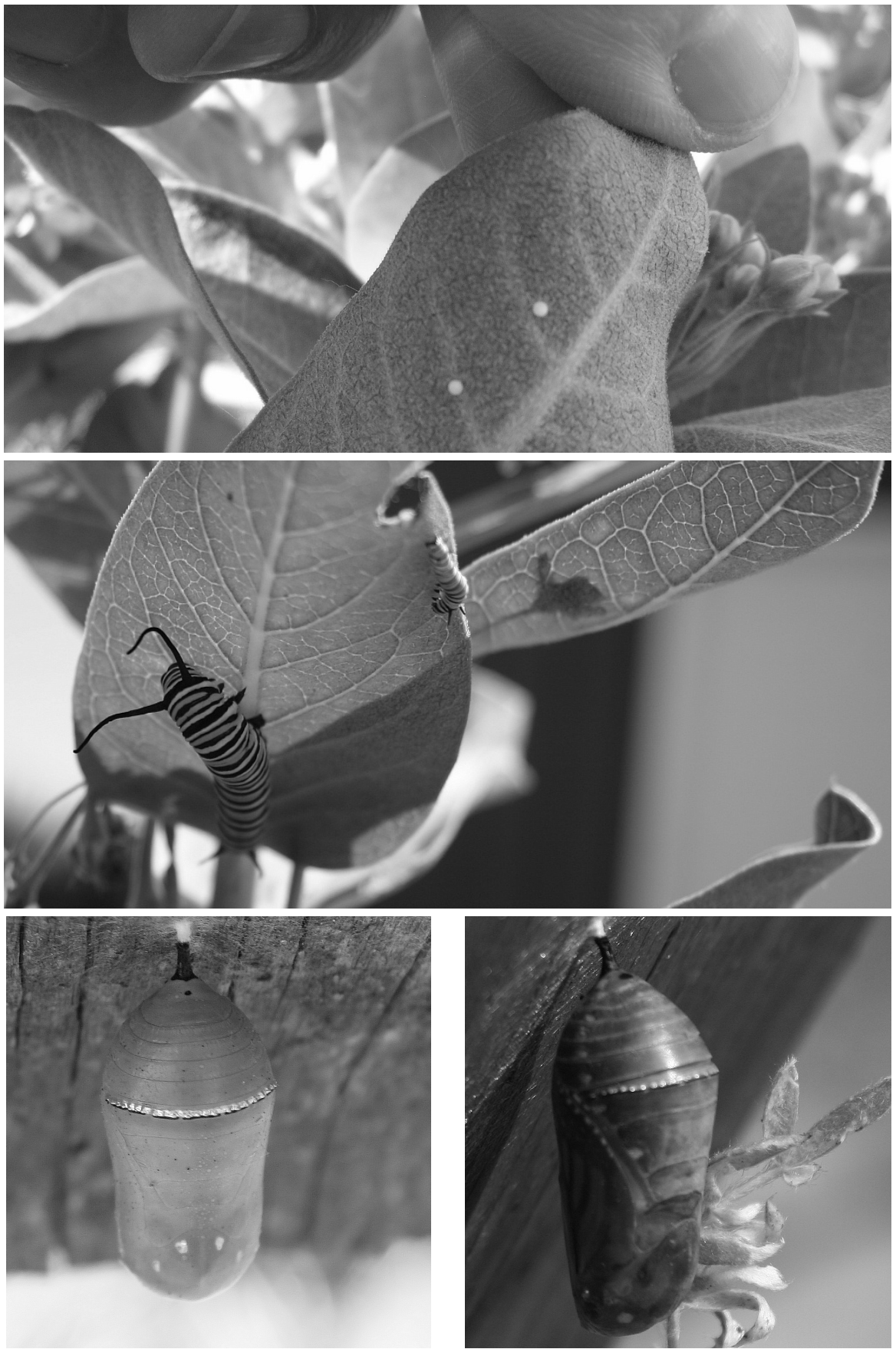

Top - Eggs; Middle - Large caterpillar (left) small caterpillar (center); Bottom Left - chrysalis early stages; Bottom Right chrysalis late stages photos - Lois Vanthuyne, EC-CWS Last Mountain Lake NWA 

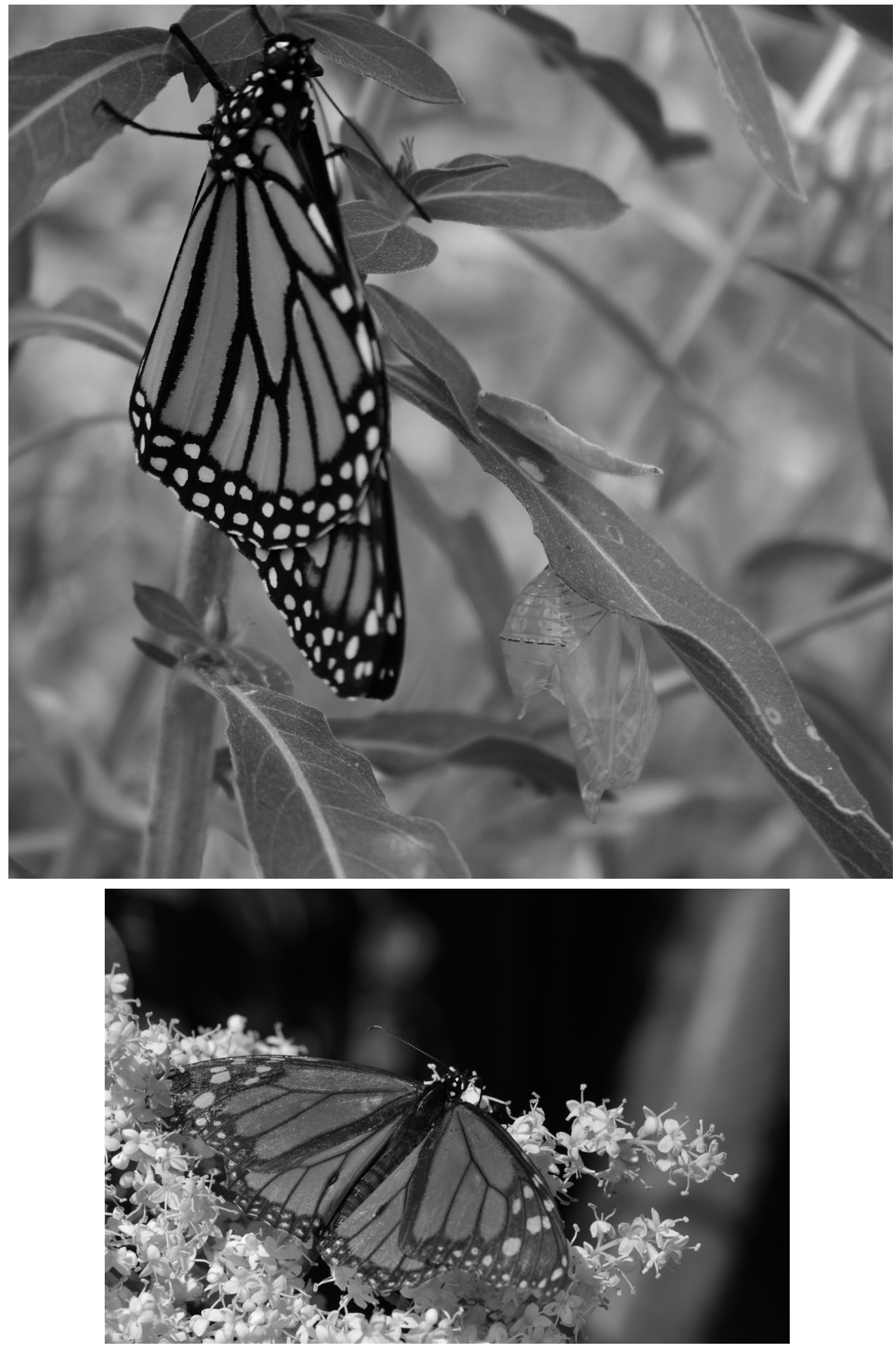

Top - new adult and empty chrysalis -Lois Vanthuyne, EC-CWS Last Mountain Lake NWA; Bottom - worn adult -Juhachi Asai 